SAR (Soedirman Accounting Review): Journal of

Accounting and Business

Journal Homepage: http://jos.unsoed.ac.id/index.php/sar/

\title{
FACTORS AFFECTING UNDERSTANDING AND USING OF STANDAR AKUNTANSI KEUANGAN TANPA AKUNTABILITAS PUBLIK ON MSMES (SURVEY CONDUCTED OF ENTREPENEURS GETUK GORENG IN BANYUMAS REGENCY)
}

\section{Thiya Septriana ${ }^{1}$, Puji Lestari ${ }^{2}$, Dona Primasari ${ }^{3}$}

International Accounting, Faculty of Economics and Business, Jenderal Soedirman, Indonesia

*Email corresponding author: thiyasetriana@gmail.com

\begin{abstract}
This research aims to determine the effect of variable Level Education, Socialization of SAK ETAP, Business Scale, and Business Age on Understanding and Use of SAK ETAP at Getuk Goreng entrepreneurs in Banyumas Regency. The sample in this study amounted to 54 entrepreneurs of Getuk Goreng in Banyumas Regency by using the census method, which is to take a sample of the population. The Theories used in this research are Human Capital Theory and Unified Theory of Acceptance and Use of Technology (UTAUT). The data collection in this research was taken by distributing questionnaires, which the process by visiting directly the place of Getuk Goreng business and submitting the questionnaire that was compiled. The results obtained from the field will be analyzed using the Validity \& Reliability Test, Classic Assumption Test, Multiple Linear Regression Test and this test is processed with SPSS application. The results of research that have been obtained show that the variable Socialization of SAK ETAP and Business Scale have a positive effect on the understanding and use of SAK ETAP while, the other variables are Level Education and Business Age do not affect the understanding and use of SAK ETAP.
\end{abstract}

Key words: Level Education, Socialiation of SAK ETAP, Business Scale, Business Size

\section{INTRODUCTION}

The Indonesian Institute of Accountants or IAI is a professional organization of all Indonesian Accountants in their position as professional as well as composing bodies of accounting standards through the Indonesian Financial Accounting Standards Board. Accounting standards oversee a number of pillars compiled by following the development of the business world, namely Financial Accounting Standards (SAK), Islamic Financial Accounting Standards (SAK Syariah), Financial Accounting Standards for Micro, Small, Medium (SAK EMKM) and Standar Akuntansi Keuangan Entitas Tanpa Akuntabilitas Publik (SAK ETAP).The statement of cash flow describes the cash inflows and outflows in the company during a predetermined accounting period. Cash flow statements began reporting required in 1987 based on SFAS No. 95. In Indonesia the obligation to report cash flows began in 1994 with the Statement of Financial Accounting Standards (PSAK) No. 2 which states that 
the company must prepare a cash flow statement and present the report as an inseparable part of the financial statements for each period of financial statement. There are three activities in the cash flow statement, namely operating, investing and financing activities. Operating activities are the main activity in the cash flow statement that presents information related to the company's operation, the company's ability to pay off debts, etc.

According to the Republic of Indonesia Law on Micro, Small and Medium Enterprises (MSMEs) No.20 of 2008 in Chapter 1, Article 1, it is explained that: "Small businesses are individual businesses or business entities that are not part of medium-sized businesses or large businesses that meet the criteria of small businesses. Medium business is an individual business or business entity that is not part of a small business or large business. Whereas large business is a business carried out by a business entity with an amount of net worth or annual sales greater than a medium business (Law No. 8 of 2008).

Based on the phenomenon that many MSMEs currently only use personal capital in running their businesses. The reason MSMEs do not use funds or capital from credit providers is the scale of business that is still small and the length of business that is still new (1-3 years). The reason for the complexity of the requirements provided by the lender. One of the conditions in the financial statements of MSMEs that reflect the true state of the company. However, many MSMEs do not provide or compile financial reports in their businesses. The reason is that MSMEs are too focused on the production and operational processes, so they do not pay attention to recording or bookkeeping (Putra and Kurniawati, 2012).

Another obstacle faced by MSMEs is the linkage with unclear business prospects and unstable planning, vision and mission. This happens because generally, MSMEs are income gathering in nature, namely rising income. This can provide convenience in accessing banks, so MSMEs must make financial reports. However, the situation in the field shows that most MSMEs do not make financial reports for KUR providers (in this case banks) so that banks are very careful in providing loans (Baas and Schrooten, 2006).

MSMEs being able to survive in a state of economic crisis but MSMEs also have a positive impact on the development of the business world, this is evidenced by the increasing number of MSMEs in Central Java Province indicating that changes in the increase in employment will have an impact on improving the living standard of the people in the surrounding area. Banyumas Regency is one of the districts located in Central Java Province with a government center in Purwokerto which is one of the most famous culinary producing areas. Banyumas Regency has a variety of culinary or 
special foods which are quite diverse including Mendoan, Tempe, Soto Sokaraja, Getuk Goreng, Nopia, and Kripik Tempe.

Decrease in the number of Getuk Goreng MSMEs in the Sokaraja area, this certainly does not have a good impact on the surrounding environment as well as the sustainability of the business of getting fried. The reason is due to increasingly fierce competition from other entrepreneurs and a lack of systematic accounting in businesses that confuse personal funds and also funds from business results. This certainly has an impact on profits earned by entrepreneurs. Profit can be used as a quantitative indicator of the success of business enterprises that can create benefits because profit is an important tool for and satisfaction for stakeholders (Suryana, 2006).

The bookkeeping problems of the getuk goreng UMKM actors also caused a decrease in the number of businesses. Bookkeeping that is not considered important results in a lack of understanding of MSMEs in making reports of their business. The business of producing getuk goreng in Sokaraja Subdistrict has an important role in the economy of Sokaraja District. This business is one of the sources of income for the local population and is also a potential business opportunity to absorb labor in the vicinity, so as to reduce the unemployment rate in Sokaraja Sub-District.

Prevention efforts must be made to prevent the decline of one of Banyumas's special foods so that its business can develop and continue to continue producing. The more tourists who are interested, then getuk goreng business will continue into the future. If it is left to the business, getuk goreng can experience extinction and decrease in number every year.

Based on data from the Department of Industry and Cooperatives (Disperindagkop) of Banyumas, the number of Getuk Goreng MSMEs in Banyumas was as many as 57 SMEs, centered in Sokaraja with 36. This makes Sokaraja one of the centers for the production and sale of getuk goreng in Banyumas Regency. The Sokaraja area which is the center of sales of Getuk Goreng is supported by its strategic location for visitors who come to Purwokerto to buy typical food in Banyumas Regency. With the sale condition of Getuk Goreng, which is centered in one area, namely sokaraja, this also has an impact on the tight competition of entrepreneurs getuk goreng, because of existing problems, MSMEs actors must increase productivity, creativity, and quality of ingredients in order to survive in competition.

Based on the problems of the getuk goreng UMKM, it can be related to the theory used in this study, Human Capital Theory and Unified Theory of Acceptance and Use of Technology (UTAUT) which explains the relationship between variables to existing problems. Where human capital theory Human capital is defined as the product of employee capability with employee commitment, thus if you want 
to multiply the performance of human resources, it is necessary to improve the quality of the two human capital components (Mulyadi, 2001)

The theory of Unified Theory of Acceptance and Use of Technology (UTAUT) that connects the extent to which an individual believes that organizational and technical infrastructure must exist to support the use of the system, namely the relationship between the variable size of business and business age. UTAUT is composed of four significant direct determinants of interest in the use and use of information systems, namely: performance expectations, business expectations, social factors and facilitating conditions (Venkatesh et al., 2003).

\section{LITERATURE REVIEW AND HYPHOTHESIS DEVELOPMENT}

\section{Human Capital Theory}

Human Capital Theory was developed by Becker \& Gary, 1962 argued that investment in training and to increase human capital are important as an investment in other forms of capital. Human Capital Theory is that investment in human resources has a large influence on increasing productivity, increasing labor productivity can be encouraged through education and training.

\section{Unified Theory of Acceptance and Use of Technology (UTAUT)}

Unified Theory of Acceptance and Use of Technology (UTAUT) is a theory developed by Vankatesh et al. (2003) The presence of technology has changed many organizations. Information technology has greatly improved performance, this technology must be accepted and used first by the wearer.

\section{Micro, Small and Medium Enterprises}

According to the Act number. 20 of 2008 article 1state Micro-business is a productive business owned by individuals and/or individual business entities. Small Business is a productive economic enterprise that is independent, carried out by individuals or business entities that are not subsidiaries or not branches of companies that are owned, controlled, or become part of either directly or indirectly from Medium. Medium Enterprises are productive economic businesses that are independent, carried out by individuals or business entities that are not subsidiaries or branches of companies that are owned, controlled, or become part of either directly or indirectly.

\section{SAK ETAP}

Standar Akuntansi Keuangan Entitas Tanpa Akuntabilitas Publik (SAK ETAP) are intended to be used by entities without public accountability. SAK ETAP, an entity that does not have significant public accountability and publishes general-purpose financial reports for external users. 


\section{Hypothesis development}

H1: The level of education has a positive effect on understanding and Using SAK ETAP of MSMES

$\mathrm{H}_{2}$ : Socialization SAK ETAP has a positive effect on understanding and Using SAK ETAP of MSMEs.

$\mathrm{H}_{3}$ : Business Size has a positive effect on the understanding and Using SAK ETAP Of MSMES

$\mathrm{H}_{4}$ : Business Size has a positive effect on the understanding and Using SAK ETAP of MSMES

The research model

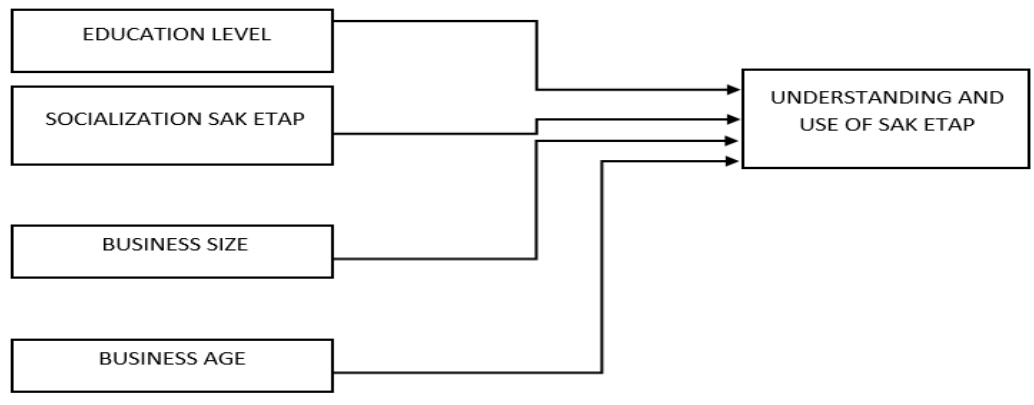

Figure 1. Research model

\section{RESEARCH METHODOLOGY}

\section{Research design}

\section{Type of research}

This study uses a quantitative approach using primary data. Where the data was obtained from distributing questionnaires directly to respondents (Getuk Goreng Entrepreneurs) in Sokaraja. Quantitative research methods can be interpreted as research methods that are based on the philosophy of positivism, used to examine certain populations or samples, data collection.

\section{Population and sample}

The population in this study were 57 entrepreneurs. The method of determining the sample according to Arikunto (2006), namely: "if the subject is less than 100, it is better to take all so that the research is population research". The technique of determining the sample using the census method ". Census method is a study of all members of the population or the number of samples equal to the population. The sample in this study were all Getuk Goreng entrepeneurs in Banyumas Regency which numbered 57 entrepreneurs. 


\section{Data collection method}

In this study the researcher use Primary data which data taken from a study using instruments performed at a certain time and the results cannot be generalized only to describe the situation at that time such as a questionnaire. Secondary data is data that has been recorded in a book or even a report but can also be a result of laboratory results, for example, from documents, journals, articles, and the internet.

\section{Operational variables}

\section{Independent variable $(X)$}

Independent variable is a type of variable that explains or influences other variables (Indriantoro, 2002). Which consist of: (a) Education Level (X1), (b) Socialization SAK ETAP (X2), (c) Business Size (X3), (d) Business Age (X4)

\section{Dependent variable $(Y)$}

The dependent variable is a variable that is influenced or which is a result, because of the existence of independent variables (Sugiyono, 2010).

To measure the financial reporting of MSME actors in accordance with SAK ETAP, an indicator needs to be determined. Financial reporting indicators for MSME players are based on SAK ETAP: (a) Balance Sheet, (b) Income Statement, (c) Cash Flow Statement, (d) Reports on Changes in Equity / Capital, (e) Notes to Financial Statements.

\section{Data analysis technique}

The technique to analyze the data is use data instrument test, classic assumption test, multiple linear regression analysis test, goodnes of fit test, and the last hypothesis test. This study will use IBM SPSS.

\section{RESEARCH RESULT AND DISCUSSION}

\section{Research Overview}

The data used in this research are primary data. The Primary data obtained from a list of statements that were answered by respondents in the research questionnaire. The term of this research began in early September 16, 2019 until October 7, 2019.

\begin{tabular}{lcc}
\hline Explanation & Total & Percentage \\
\hline Questionnaire Distributed & 57 & $100 \%$ \\
Questionnaire rejected & 2 & $3.5 \%$
\end{tabular}




$\begin{array}{lcc}\text { Questionnaire didn't return } & 1 & 1.8 \% \\ \text { Questionnaire Processed } & 54 & 94.7 \%\end{array}$

Source: Data processed, 2019

\section{Data Quality Test}

- Validity Test Results Based on the three tables above, known that Corrected Item Total Correlation ( $\left.r_{\text {count }}\right)$ to the Understanding and use of SAK ETAP variables, Education Level, SAK ETAP Socialization, Business Scale, Business Age is greater than $r_{\text {table }}(0.361)$ at $5 \%$ significance, so it has meaning thus all items are considered valid.

- Reliability Test Results Based on the reliability test results above, it can be seen the Conbrach Alpha value on the Understanding and use of SAK ETAP variable, Education Level, SAK ETAP Socialization, Business Scale, Business Age shows $>0.60$. So, it can be concluded that all statement items for each variable are declared Reliable. Then, the questionnaire can be used in further research

\section{Classical Assumption Test}

\section{Normality test}

Table 4. 1 Normality Test results

\begin{tabular}{lccc}
\hline Variable & Asymp.sig. & $\alpha$ & Explanation \\
\hline Unstandardized Residual & 0.448 & 0.05 & Normal \\
\hline
\end{tabular}

Source: Data processed, 2019

K-S data processing results obtained asymp.sig (2-tailed) value of 0.448 where the calculation value is greater than $\alpha$ that is 0.05 so it can be concluded that the residual data in this study are normally distributed.

\section{Multicollinearity Test}

Table 4. 2 Multicollinearity Test

\begin{tabular}{lccl}
\hline \multicolumn{1}{c}{ Variable } & $\begin{array}{c}\text { Tolerance } \\
>0,1\end{array}$ & $\begin{array}{c}\text { VIF } \\
<10\end{array}$ & \multicolumn{1}{c}{ Explanation } \\
\hline Level education (X1) & 0.809 & 1.235 & There is No Multicollinearity \\
Socialization SAK ETAP (X2) & 0.890 & 1.123 & There is No Multicollinearity \\
Business Scale (X3) & 0.681 & 1.468 & There is No Multicollinearity \\
Business Age (X4) & 0.746 & 1.340 & There is No Multicollinearity \\
\hline
\end{tabular}

Source: Data processed, 2019 
Based on the Multicollinearity test results, it can be seen that the tolerance value in this research is $>0.1$ and VIF value $<10$, it can be concluded that the research doesn't contain multicollinearity on the Understanding and use of SAK ETAP variables, Education Level, Socialization SAK ETAP, Business Scale, and Business Age. So this variables are feasible to use for further analysis.

\section{Heteroscedasticity Test}

Park Test is a method that is used by squaring the residual value $\left(\mathrm{U}^{2} \mathrm{i}\right)$ and regressing the LN2 $\mathrm{i}$ variable into a dependent variable.

Table 4. 3 Heteroscedasticity test

\begin{tabular}{lcl}
\hline \multicolumn{1}{c}{ Variable } & Sig. & \multicolumn{1}{c}{ Explanation } \\
\hline Level education (X1) & 1.235 & Theres is No Heteroscedasticity \\
Socialization SAK ETAP (X2) & 1.123 & Theres is No Heteroscedasticity \\
Business Scale (X3) & 1.468 & Theres is No Heteroscedasticity \\
Business Age (X4) & 1.340 & Theres is No Heteroscedasticity \\
\hline
\end{tabular}

Source: Data processed, 2019

Based on the results of the Heteroscedasticity Test on the Understanding and use of SAK ETAP variables. Variable Education Level, SAK ETAP Socialization, Business Scale, Business Age showed significance results of $>0.05$. Thus, all variables are stated to not occur with symptoms of heteroscedasticity. And research can be continued at a later stage.

\section{Autocorrelation Test}

To determine the existence of autocorrelation or not, it can be seen the value of Durbin Watson:

Table 4. 4 Autocorrelation

Model Summary

\begin{tabular}{cccccc}
\hline Model & $\mathrm{R}$ & R Square & $\begin{array}{c}\text { Adjusted } \mathrm{R} \\
\text { Square }\end{array}$ & $\begin{array}{c}\text { Std. Error of the } \\
\text { Estimate }\end{array}$ & Durbin-Watson \\
\hline 1 & $.000^{\mathrm{a}}$ & .000 & -.082 & .14833534 & 1.741 \\
\hline
\end{tabular}

a. Predictors: (Constant), X4, X2, X1, X3

b. Dependent Variable: Unstandardized Residual\\ 
The results of data processing with SPSS above, it can be seen that the value of Durbin Watson in this test is 1.741 which is the autocorrelation test value, namely independence between residuals (pres $=0$ ). Then this value is compared with the $\mathrm{dU}$ and $\mathrm{dL}$ values in the Durbin-Watson Statistics table $5 \%$ significance with $\mathrm{N}=54$ and $\mathrm{k}=4$, the value of $\mathrm{dL}=1,407$ and $\mathrm{dU}=1,723$ are obtained (Appendix 8). The DW value is greater than the $d U$ value $(1,741>1,723)$ and the $D W$ value is less than $4-1,741$ $(2,259)$ or $1,741<2,259$, which means there is no positive autocorrelation in this study and no decision. Thus, the data in this study do not have autocorrelation.

\section{Multiple Regression Analysis}

Based on the multiple regression analysis test using the SPSS program the following results are obtained:

Table 4. 5 Multiple regression analysis

\begin{tabular}{|c|c|c|c|c|c|c|c|}
\hline \multirow{2}{*}{ Model } & \multicolumn{2}{|c|}{$\begin{array}{l}\text { Unstandardized } \\
\text { Coefficients }\end{array}$} & \multicolumn{3}{|c|}{ Standardized Coefficients } & \multicolumn{2}{|c|}{ Collinearity Statistics } \\
\hline & $\mathrm{B}$ & $\begin{array}{l}\text { Std. } \\
\text { Error }\end{array}$ & Beta & $\mathrm{T}$ & Sig. & Tolerance & VIF \\
\hline 1 (Constant) & 2.679 & .291 & & 9.203 & .000 & & \\
\hline $\mathrm{X} 1$ & .013 & .047 & .034 & .285 & .777 & .809 & 1.235 \\
\hline $\mathrm{X} 2$ & .301 & .063 & .550 & 4.810 & .000 & .890 & 1.123 \\
\hline X3 & .021 & .010 & .269 & 2.060 & .045 & .681 & 1.468 \\
\hline $\mathrm{X} 4$ & -.004 & .008 & -.060 & -.477 & .635 & .746 & 1.340 \\
\hline $\mathrm{R}$ & .656 & & & & & & \\
\hline R Square & .430 & & & & & & \\
\hline Adjusted R & .384 & & & & & & \\
\hline Squer & & & & & & & \\
\hline $\mathrm{F}_{\text {sig }}$ & .000 & & & & & & \\
\hline $\mathrm{F}_{\text {count }}$ & 9.254 & & & & & & \\
\hline Ftable & 2.56 & & & & & & \\
\hline
\end{tabular}

a. Dependent Variable: $Y$

Based on the results of the multiple regression test in the table above we get the following regression equation:

$$
Y=2.679+0,013 \times 1+0.301 \times 2+0.021 \times 3-0.004 X 4
$$

The equation shows the following:

1. The results of the multiple regression analysis show a constant of 2,679 which means that when the value of all independent variables is 0 , then the size of the implementation of SAK ETAP $(Y)$ is added 2.679 with variance that cannot be explained by the independent variable.

2. Level Education (X1) 
The Educational Background regression coefficient (X1) of 0.013 states that if each increase in the educational background variable (X1) is one unit, it will cause an increase or increase in the implementation of SAK ETAP by -0.013 units assuming the business size and business life is permanent.

3. Socialization of SAK ETAP (X2)

Regression coefficient of SAK ETAP Socialization (X2) of 0.301 states that if every increase of the SAK ETAP Socialization variable (X2) is one unit, it will cause an increase or increase in the implementation of SAK ETAP by 0.301 units assuming business size and business life is permanent.

4. Business Size (X3)

Regression coefficient of Business Size (X3) of 0.021 states that if each increase in the business size variable (X3) is one unit, it will cause an increase or increase in the implementation of SAK ETAP by 0.021 unit assuming educational background and business life is permanent.

5. Business Age

Business Life Regression coefficient (X4) of -0.004 states that if each increase in the business age variable (X4) is one unit, it will cause an increase or increase in the implementation of SAK ETAP by -0.004 units assuming educational background and business size is permanent.

\section{Determinant Coefficient Test (R2)}

Adjusted recommended because this value will not changes even though there are additional independent variables into the model, so that the determination coefficient 0.430 or $43 \%$. It can be interpreted that the independent variables education level, SAK ETAP socialization, business age and business size has effect on Understanding and Use of SAK ETAP variables as $43 \%$. While the remaining $57 \%$ is explained by other factors not tested in this research.

\section{F test}

The results of the regression equation from the data above can be seen that the value of $F_{\text {count }}$ is 9,254 , while the value of Ftable is 2.56 (appendix 8), because $F_{\text {count }}>F_{\text {table, }}$ and the significance value of $0,000<0.05$ then $\mathrm{Ho}$ is rejected and $\mathrm{Ha}$ is accepted, this means together variable Education Level, SAK ETAP Socialization, Business Scale, Business Age influence the dependent variable Understanding and use of SAK ETAP

\section{T Test}

Based on the results of the hypothesis test in the table above, $t$ test are as follows: 
- $T$ test results on the Education Level variable ( $X 1)$ obtained t-count value of -0.285 with a significance of $0.777>0.05$, and a $\beta$ value of -0.034 so it can be concluded that the Education Level has no effect on the implementation of SAK ETAP, then $\mathrm{H} 1$ is declared rejected.

- T test results on the SAK ETAP Socialization variable (X2) obtained t value of 4.81 with a significance of $0.000<0.05$, and a $\beta$ value of 0.550 so that it can be concluded that the SAK ETAP Socialization has an effect on the implementation of SAK ETAP, then $\mathrm{H} 2$ is accepted.

- T test results on the business size variable (X3) obtained $t$ value of 2.06 with a significance of $0.045<0.05$, and a $\beta$ value of 0.269 so that it can be concluded that business size influences the implementation of SAK ETAP, then $\mathrm{H} 3$ is declared acceptable.

- T test results on the business age variable $(X 4)$ obtained $t$ count value of -0.477 with a significant value of $0.635>0.05$, and a $\beta$ value of -0.060 so it can be concluded that business life has no effect on the implementation of SAK ETAP, then $\mathrm{H} 4$ is declared rejected.

\section{RESEARCH DISCUSSION}

\section{Effect of Education Level on understanding MSMEs about SAK ETAP}

Human capital theory said that the higher the level of education, the more influenced on the implementation of financial statements. The implication of Human Capital Theory in this research used as a basis to explain how the level of education of the owner can influence the implementation of SAK ETAP in MSMEs. Based on the data in quisionares, this reseach shows that the majority of entrepreneurs in the education is most of senior high school education which is the entrepreneurs doesn't understand about financial statement and not interested to make Financial statement based on SAK ETAP.

Based on the results of hypothesis testing, the level of education on the understanding and use of SAK ETAP was declared rejected. This is indicated by the significance in this study 0.777 is greater than 0.05 , where the value is greater than the significance level of $5 \%$. Means it can be concluded that the level of education does not affect the understanding of MSMEs in preparing financial reports based on SAK ETAP.

The reason for this research was not accepted because most of the respondents education is Senior high school, with the majority non-accounting educational background. This is one of the factors in the latest education level which does not affect perceptions about the importance of bookkeeping. Based on the results of the data show that the dominated number entrepreneurs is graduated from Senior high school background as much as $51.8 \%$ or equals with 28 entrepreneurs. The other education background for not school is only one person or 1.9\%, elementary School only 2 
person or 3.7\%, Junior high school it was 7 person or $13 \%$ and for bachelor or diploma has 16 person or $29.6 \%$, which makes the supporting factor in this hypothesis is rejected with the highest number of senior high school background making entrepreneurs lack experience of Accounting. Rudiantoro and Siregar (2012) also stated that if MSMEs business actors did not have an accounting education background, then business actors would not consider bookkeeping important to be done regularly.

The Influence of Socialization SAK ETAP on the understanding of MSMEs.

Based on Human Capital Theory is a thought that considers that humans are a form of capital or capital goods as other capital goods, such as land, buildings, machinery, and so on. Human capital can be defined as the total amount of people's knowledge, skills and intelligence. This is in line with existing research that accounting knowledge should be able to help in the bookkeeping process which is able to give effect to financial management, starting from the separation of business and private money, which so far many MSME actors still do not care about bookkeeping, so from this the socialization as a supporter of human capital theory has a positive influence on this research.

Based on the results of this research indicate that the increase or decrease during the study period significantly affects MSMEs' understanding of SAK ETAP (y). This is indicated by the significance in this study 0,000 is smaller than 0.05 . Where the value $<$ of the $5 \%$ significance level. Means, it can be concluded that the variable socialization SAK ETAP affects the understanding of MSMEs in preparing financial reports based on SAK ETAP.

The reason for the hypothesis in this study was accepted because most MSMEs had participated in the socialization of financial statements and obtained material on SAK ETAP, most of them has alredy participated in the socialization regarding the preparation of simple financial statements. Where indirectly the preparation of financial statements taught are financial statements based on SAK ETAP. Because, when the respondent heard the term SAK ETAP, some of them already understood and answered that they already knew.

\section{Effect of Business Size on the understanding of MSMEs based on SAK ETAP}

Unified Theory of Acceptance and Use of Technology (UTAUT) which explains that the adoption of information systems can be used if there are conditions that support (Facilitating Conditions). Where a large scale of business implies more companies can provide supporting facilities. Based on the results obtained, the greater the scale of the business tested by the indicator of the number of employees giving results in accordance with this theory, the larger the scale the more employees who have in helping the production process. 
Based on the results of this study the significance of business size is 0.045 . This value is smaller than the $5 \%$ significance level, which means that the size of MSMEs business has a significant effect on MSMEs understanding of SAK ETAP. Pinasti (2001) states that business size is a factor that is difficult to separate from the environment of MSME entrepreneurs. The size of the business can influence the thinking of entrepreneurs related to complexity and the higher level of company transactions so that it is expected that the greater size of the business can encourage someone to think and learn about solutions to deal with it.

\section{Effect of Business Age on the understanding of MSMEs based on SAK ETAP}

This research is not in line with the Unified Theory of Acceptance and Use of Technology (UTAUT) which explains that the adoption of information systems can be used if there are conditions that support (Facilitating Conditions). Where the old and new business age not only requires capital for their business but to control the resources within the company, so it supports to imply SAK ETAP, but there is a long business life also allows MSMEs not to do the recording because they are deemed not in need more capital for its business so that it does not implement SAK ETAP and activities that have not changed in terms of needs from year to year.

Based on the results of the hypothesis testing the Business Age variable on the understanding and use of SAK ETAP was declared rejected. This is indicated by the significance in this study 0.365 is greater than 0.05 . Where the value exceeds the significance level of $5 \%$. Means it can be concluded that the age of the business does not affect the understanding of MSMEs in preparing financial reports based on SAK ETAP

The reason for this research hypothesis is not accepted because the fact in the field shows that the business age does not guarantee the company in using SAK ETAP because the MSMEs do not think they need financial reports because they are too complicated in addition to the company activities that do not experience many changes from year to year. Requires additional capital for the company, the SMEs do not use financial reports even though the age of business has been long. According to Anderson and Eshima (2011), younger companies are more likely to have a more flexible and reactive organizational structure than older companies, and also have a higher entrepreneurial nature.

Supported by data showing that most of the entrepreneurs have a long business life of $48.1 \%$ for the business age of 20-75 years of business establishment, for other business age less than 20 years as much as 22 MSMEs or equals $40.7 \%$ and more than 25 years its only 7 MSMEs or equals $13 \%$. Based on the information in the field, most entrepreneurs have felt safe and satisfied with the 
income they have received so that they consider that they do not need more bookkeeping for the company so that their business is stable and does not experience significant development.

\section{CONCLUSION AND IMPLICATION}

\section{Conclusions}

1. Education Level Has no effect on the understanding and use of SAK ETAP in Getuk Goreng Business actors in Banyumas Regency.

2. The socialization of SAK ETAP affects the understanding and use of SAK ETAP in the Getuk Goreng Business actors in Banyumas Regency.

3. Business Scale influences the understanding and use of SAK ETAP in Getuk Goreng Business actors in Banyumas Regency.

4. Business Age Has no effect on the understanding and use of SAK ETAP in Getuk Goreng Business actors in Banyumas Regency.

\section{Implications}

Based on the conclusions, the implications of this research as an theoretical implications are proven that the socialization of SAK ETAP and Business Scale influences the understanding and use of SAK ETAP in MSMEs. The financial performance of MSMEs can be improved through the company's ability to manage financial aspects, manage employee. The results of this research are expected to strengthen the development of science, especially in the field of MSMEs. Related to human capital theory explains that individuals are an important asset as a support system for the company, related with this research where increasing socialization will be affects the understanding of MSMEs in recording financial statements. MSMEs requires socialization from the government as a provision to gain knowledge about bookkeeping. In line with this theory, the more MSMEs do not have an accounting background, it will be difficult to do bookkeeping. In this research, entrepreneurs with a senior high school background less understood about bookkeeping so the hypothesis in this study is rejected.

Unified Theory of Acceptance and Use of Technology (UTAUT) which states that facilitating support as in this research is in accordance with the results which state that the scale of the business measured by the number of employees is able to give effect in financial reporting, then the hypothesis is accepted while business age is not a supporting factor in running the business because MSMEs feel they are feeling enough with existing income so, it does not really need the system this is not in accordance with the UTAUT theory which states the supporting facilities of the business life factor 


\section{Research limitation}

1. This research only examines Factors of Education Level, SAK ETAP Socialization, Business Scale and Business Age. The next research is expected to add another independent variable, so that it is most likely to be measured to have an effect or significant.

2. This research was conducted using a questionnaire, this allows respondents not to answer truthfully to each question. It is expected that further researchers will be able to enter a number of open questions that can help in analyzing the research results of the respondents.

3. In this study the independent variable gives an effect of $43 \%$ this can be interpreted that there are still other factors of $57 \%$ which are not included in this study. It is hoped that the researchers will then be able to include additional variables that have the potential to influence the understanding and use of SAK ETAP.

4. The need for serious attention from relevant agencies towards the development of small and medium enterprises, especially in terms of the obligations of carrying out bookkeeping as well as conducting intense training and conducting comprehensive socialization to entrepreneurs or MSMEs.

\section{REFERENCES}

Baas, T. dan M. Schrooten. (2006). Relationship Banking and SMEs: A Theoretical Analysis. Small Business Economics, 27

Becker, G. S. (1962). Invesment Human Capital : A Theorical Analysis. The Journal of Polotical Economy. 70. 9-49.

Anderson, B.S. and Y. Eshima. (2011). The Influence of Firm Age and Intangible Resources on the Relationship between Entrepreneurial Orientation and Firm Growth among Japanese Smes. Journal of Business Venturing.

Arikunto, Suharsimi, (2006). Metode Penelitian: Prosedur Penelitian. Suatu Pendekatan Praktik. Jakarta: Rineka Cipta.

Mulyadi. 2001. Sistem Akuntansi Edisi Tiga. Jakarta : Salemba Empat.

Pinasti, M. (2001). Penggunaan Informasi Akuntansi dalam Pengelolaan Usaha Para Pedagang Kecil di Pasar Tradisional Kabupaten Banyumas. Jurnal Ekonomi, Bisnis dan Akuntansi No. 1/Vol. 3/Mei.

Putra, Hermon Adhy dan Kurniawati, Elisabeth Penti. (2012). Penyusunan Laproan Keuangan untuk UKM Berbasis Standar Akuntansi Keuangan Entitas Tanpa Akuntanbilitas Publik (SAK ETAP) dalam Proceeding for Call Paper PEKAN ILMIAH DOSEN FEB-UKSW, Salatiga

Rudiantoro, Rizki dan Siregar, Sylvia Veronica. (2012). Kualitas Laporan Keuangan Umkm Serta Prospek Implementasi Sak Etap. Jurnal Akuntansi dan Keuangan Indonesia. Volume 9. 
Suryana. (2006). Kewirausahaan Pedoman Praktis : Kiat dan Proses menuju sukses. Edisi Ketiga. Penerbit Salemba. Jakarta.

Adiati, Adis Puspita. (2018). Faktor-Faktor Yang Mempengaruhi Implementasi Standar Akuntansi Keuangan Entitas Tanpa Akuntabilitas Publik Pada Umkm. Fakultas Ekonomi. Universitas Islam Indonesia Yogyakarta Mallaret. (2008). Berbisnis dengan osama mengubah resiko global menjadi peluang sukses. Jakarta: Serambi Ilmu Semesta

Nugroho, Diki Maulana. (2017). Pengaruh informasi dan sosialisasi akuntansi, serta ukuran usaha terhadap pemahaman umkm atas standar akuntansi keuangan entitas tanpa akuntabilitas publik (sak etap) (studi pada umkm batik di surakarata). Fakultas Ekonomi Dan Bisnis Islam Institut Agama Islam Negeri Surakarta. Surakarta.

Rahmawati ,Teti dan Puspasari, Oktaviani Rita. (2017). Implementasi Sak Etap Dan Kualitas Laporan Keuangan Umkm Terkait Akses Modal Perbankan. Jurnal Kajian Akuntansi. Vol 1

Solovida, GracceTiana. (2003). Analisis Faktor -Faktor yang mempengaruhi Penyiapan dan Penggunaan Informasi Akuntansi pada Perusahaan Kecil dan Menengah Di Jwa Tengah. Tesis Program Pasca sarjana Magister akuntansi Universitas Diponegoro. Semarang.

Undang - undang Republik Indonesia No. 8 Tahun 1997 tentang kriteria perusahaan.

Undang-Undang Republik Indonesia No. 20 Tahun 2008 tentang Usaha Mikro Kecil dan Menengah.

Van Hemert, P., E. Masurel, and P. Nijkamp. (2011). The Role of Knowledge Sources of SME's for Innovation Perception and Innovation Policy.Workingpaper.http://dare.ubvu.vu.nl/bitstream/1871/24072/1/rm\%20201139.pdf

Winarni Sri. (2006). Strategi Pengembangan Usaha Kecil Melalui Peningkatan Aksesibilitas Kredit Perbankan. Infokom No. 29 Tahun XXII. 23

Wiyono, Gendro. (2011). Merancang penelitian Bisnis dengan alat analisis SPSS 17.0 dan SmartPLS 2.0. Yogyakarta: UPP STIM YKPN.

Yasa, K. S. H., Herawati, N. T., Sulindawati, N. L. G. E. (2017). Pengaruh Skala Usaha, Umur Perusahaan, Pengetahuan dan Akuntansi Terhadap Penggunaan Informasi Akuntansi Pada Usaha Kecil Menengah (UKM) di Kecamatan Buleleng dengan Ketidakpastian Lingkungan Sebagai Variabel Pemoderasi. e-Journal S1 Ak Universitas Pendidikan Ganesha Jurusan Akuntansi Program S1, $8(2)$. 